\title{
Halkla İlişkilerde Karar Alım Süreçlerine Etki Eden Faktörlerin Bilişsel Haritalama Yöntemi ile Değerlendirilmesi
}

\author{
Aslı İcil Tuncer \\ M.Umut Tuncer
}

yardımcı doçent, adnan menderes üniversitesi, iletişim fakültesi asliicil@gmail.com

m.umut.tuncer@adu.edu.tr

\begin{abstract}
Evaluation of Factors Affecting Public Relations Decision Making Processes by Cognitive Mapping Method

This research aims to draw a theoretical and empirical framework for explaining how the environment affects public relations decisions. Thus, it aims to discuss the factors that affect the public relations practices, to explain the relations between these factors and to explore the points of origin of the decisions taken in public relations. In the research, public relations practitioners of the companies that are on the list of Turkey's 100 most valuable brands prepared by Brand Finance were interviewed. With cognitive mapping method, centrality ratios and densities of factors affecting public relations decisions were analysed, cognitive mapping template and neighbourhood matrix were formed. According to the results, in the decisions of public relations, the internal factors, especially the decision makers and the cost factors, are more prevalent than the macro environment. On the other hand, it has been observed that social media and country agendas have an important influence on public relations decisions.
\end{abstract}

keywords: public relations, decision making, cognitive map, environment, public relations practitioners

Bu makaleye referans vermek için: Tuncer i. A., ve Tuncer M. U., (2017). Halkla Iliş̧kilerde Karar Alım Süreçlerine Etki Eden Faktörlerin Bilişsel Haritalama Yöntemi ile Değerlendirilmesi. Galatasaray Üniversitesi Ileti-ş-im Dergisi, 27, 33-56. 


\section{Résumé}

\section{Évaluation des facteurs affectant les processus de prise de décision en relations publiques par la méthode de cartographie cognitive}

Cette recherche vise à établir un cadre théorique et empirique pour expliquer comment l'environnement affecte les décisions de relations publiques. Ainsi, il vise à discuter les facteurs qui affectent les pratiques de relations publiques, à expliquer les relations entre ces facteurs et à explorer les points d'origine des décisions prises dans les relations publiques. Dans le cadre de la recherche, des les praticiens des relations publiques des entreprises figurant sur la liste des 100 marques les plus précieuses de Turquie, préparée par Brand Finance, ont été interviewés. Avec la méthode de cartographie cognitive, les ratios de centralité et les densités de facteurs affectant les décisions de relations publiques ont été analysés, le modèle de cartographie cognitive et la matrice de voisinage ont été formés. Selon les résultats, dans les décisions de relations publiques, les facteurs internes, en particulier les décideurs et les facteurs de coût, sont plus importants que le macro-environnement. D'un autre côté, il a été observé que les médias sociaux et les agendas des pays ont une influence importante sur les décisions de relations publiques.

mots-clès : relations publiques, prise de décision, carte cognitive, environnement, praticiens des relations publiques

\section{Öz}

Bu araştırma, ortamın halkla ilişkiler kararlarını nasıl etkilediğini açıklamak için teorik ve ampirik bir çerçeve çizme amacındadır. Böylece, halkla ilişkiler uygulamalarını etkileyen faktörleri tartışmayı, bu faktörler arasındaki ilişkileri açıklamayı ve halkla ilişkilerde alınan kararların çıkış noktalarını keşfetmeyi hedeflemiştir. Araştırmada Brand Finance'ın hazırladığı Türkiye'nin en değerli 100 markası listesinde yer alan şirketlerin halkla ilişkiler uygulayıcıları ile yüzyüze görüşmeler gerçekleştirilmiştir. Bilişsel haritalama yöntemi ile, halkla ilişkiler kararlarına etki eden faktörlerin merkeziyet dereceleri ve yoğunlukları analiz edilmiş, bilişsel haritalama şablonu ve komşuluk matrisi oluşturulmuştur. Sonuçlara göre halkla ilişkiler kararlarında makro ortamdan daha ziyade iç ortamdaki faktörler, özellikle karar alıcllar ve maliyet faktörleri öncelenmektedir. Öte yandan sosyal medya ve ülke gündemlerinin halkla ilişkiler kararlarında önemli bir etkiye sahip olduğu gözlenmiştir.

anahtar kelimeler: halkla ilişkiler, karar alımı, bilişsel harita, ortam, halkla ilişkiler uygulayıcısı 


\section{Giriş}

Halkla ilişkiler en yalın haliyle örgüt ve onun ortamı arasındaki etkileşimleri yöneten bir işlev olarak tanımlandığında, bir yanda sınırlarını korumak ve genişletmek isteyen örgütten, diğer yanda ise örgütün politikalarını sorgulayan ve baskılayan gruplardan yani örgütün ortamından söz etmiş oluruz. Bu açıklamada örgüt ve ortam keskin sınırları olan birer taraf gibi görünür. Ancak yönetilen etkileşim, ortamın örgüt kararlarını etkilemesini ve örgüt kararlarının ortamı etkilemesini sağlayarak ortam ile örgütü griftleştiren bir katalizör işlevi görür. Nihayetinde örgüt ortamına sıkı sıkıya bağlıdır. Etkileşimden kaçamaz fakat ortamı kontrol ve/veya ortama adaptasyon (Grunig, 1984) yollarından birini ya da konular bağlamıyla her ikisini seçerek ortamla ilişkilerini şekillendirebilir. Her iki yolda da halkla ilişkilerin işlevi, örgütün sınırından ortamın kapısını açan bir anahtar gibi resmedilebilir.

Şüphesiz birkaç adım ötede halkla ilişkileri, hem örgütün sınırlarının ötesindeki bilgileri sınır aşıcı rolü ile örgüte getiren hem de bu bilgileri süzerek stratejik programına dahil eden bir yönetim fonksiyonu olarak görmek mümkündür. Ne var ki ortam, halkla ilişkiler uygulayıcısının bu ideal rolü için sürekli yeni belirsizlikler yaratan bir akış halindedir (Holtzhausen, 2000). Tam da bu sebepten tek başına ortamdaki bileşenlerin neler olduğunu açıklamak, halkla ilişkilerin uygulamalarına yönelik kararların önceliklerini ve ortamın kararları nasıl etkilediğini anlamaya yetmez.

Bugün halkla ilişkiler teorisi, merkezine örgütleri değil, ortamla ilişkileri yerleştirirken geleneksel yollar dış alanlardaki saflara doğru ilerlemektedir. O halde "uygulayıcılar, kararlarına etki eden değişkenleri nasıl tanımlamaktadır?", "halkla ilişkiler uygulayıcısının kararlarında merkezi önemi olan ortam değişkenleri hangileridir?" ve "bu değişkenler arasındaki ilişkiler nelerdir?" sorularına yanıt vermek için ortam ve örgüt arasındaki etkileşimlerden doğan örüntülerin nasıl oluştuğunu anlamaya odaklanmak gerekir. Nihayetinde ortamın ölçeği ya da karmaşıklığı yerine etkilerin merkeziyetine ve kararlara yansımasına yönelik bir tartışma, örgütün davranışını anlamak için o davranışa etki eden koşulları anlamada bütüncül bir kavrayış sunma imkanına sahiptir. Bu araştırma, ortamın halkla ilişkiler uygulayıcılarının kararlarına nasıl etki ettiğini sistematik biçimde tartışma ve bu tartışma için teorik ve ampirik bir çerçeve çizme arayışındadır. Böylece, halkla ilişkiler uygulamalarını etkileyen değişkenler tartışılacak, dahası değişkenler arasında ilişkilerin olup olmadığını açıklanarak halkla ilişkiler programlarının çıkış noktaları keşfedilecektir. Araştırmanın keşfetmeyi umduğu bu çıkış noktalarını kavramak, halkla ilişkilerin karar alma biçimlerini açığa çıkarmanın yanında uygulayıcıların bugünkü konumları üzerinden bir değerlendirmeyi de imkanlı kılacaktır. Bu değerlendirmeden önce çalışmanın ardalanında yer alan kavramsal çerçevelerden söz etmek yerinde olur. 


\section{Kavramsal Çerçeve}

Grunig ve Hunt'ın mükemmellik teorisi uzun yıllar, hem halkla ilişkiler araştırmalarına rehberlik eden hem de etik halkla ilişkiler uygulamalarını açıklayan egemen paradigma olmuştur. Ancak zamanla, iletişim ve ilişkilerin karmaşıklığını açıklayan alternatif birkaç teori halkla ilişkiler eleştirel ve enstürmantalist geleneğine meydan okuyacak biçimde gelişmiştir. Macnamara (2016, s.147) alanın ileriye taşınmasına yardımcı kavramsal çerçeveleri, ilişki yönetimi teorisi, stratejik iletişim, retorik, diyolojik teori, etkileşim ve sosyo-kültürel teoriler olarak açıklamaktadır. Bu araştırmada Macnamara'nın (2016, s.147) tanımladığı çerçeveler içinden örgütün ortamı ile ilişkisinin etkileşimle mümkün olduğu varsayımından hareketle etkileşim çerçevesi teorik ardalan olarak belirlenmiştir.

Etkileşim teorisi, insanların kişisel ilgiler, eğlence ve önemli bir şeylerin parçası olma gibi farklı durumlarda etkileşim kurmaya motive oldukları fikriyle, temelde psikoloji alanından açıklanmaktadır. Öte yandan etkileşim, başka alanlarda başka odaklarla da tanımlamıştır. Örneğin Huo vd. (2010) çalışmalarında, etkileşimi kişilerarası bir yönelimle, Mersey vd. (2012) pazarlamayla ve Vivek vd. (2012) de gazetecilik yönelimiyle tartışmıştır.

Etkileşim farklı alanlarda ilgi görmesine rağmen, halkla ilişkiler alanındaki değerini ilk açıklayan Edelman's (2008) olmuştur. Sonrasında, Halkla Illişkiler Araştırmaları (Journal of Public Relations Research) ve Halkla Illişkiler Dergisi'nin (Public Relations Review) 2014 yılındaki özel sayılarıyla ilgi hızla artmıştır (Dhanesh, 2017, s.1). Dijital dünyanın etkileşimle varolması, özellikle sosyal medya ve halkla ilişkiler yazının etkileşim kavramı etrafında toplanmasının nedenlerinden biri olduğunu düşündürmektedir.

Etkileşim teorisinin izlerini konu yönetimi ve kriz yönetiminde, (Byrd, 2012) kurumsal sosyal sorumlulukta (Johansen ve Nielsen, 2011; Kim ve Lee, 2012), yeni ve sosyal medya kullanımında (Men ve Tsai, 2014) görmek mümkündür. Her ne kadar, Macnamara (2016) etkileşimi bağımsız bir paradigma olarak açıklasa da farklı çalışmalar teoriyi başka teorilerin içinden tartışmaktadır. Örneğin, Botan ve Taylor (2004) etkileşimi, birlikte yaratım perspektifi içinden, örgüt ve paydaşların anlam yaratma süreci olarak açıklamış, Taylor ve Kent (2014) ise etkileşimi, dialog teorisinin tam merkezi içinde konumlandırmıştır. Zira etkileşim diyoloğun bir "parçasıdır" ve bu yolla örgütler ve kamular sosyal sermayeye katkıda bulunacak kararlar verebilirler. Dahası etkileşim, diyalogun ne olduğunu ya da ne olmadığını anlamaya yardımcı olur. Bu farklı izlekler, etkileşimin halkla ilişkiler alanının zeminine nasıl yayıldığını da kanıtlar gibidir. Gerçekten de etkileşim halkla ilişkiler programları ile kurulacak ilişkilerin en yalın başlangıç noktasını oluşturur. O halde, etkileşimi ilişki yönetimi çerçevesinden okumak, bu zemini genişletmeye yarayabilir. Illişki yönetiminin ilişkideki grupların taraflar olarak değil, birbirleri ile etkileşim halinde olan ve gruplardan birinde bir değişiklik olduğunda diğerinde de değişimi öngören doğası bunu mümkün kılmaktadır. Örgüt ve ortamı arasındaki 
bağlar, etkileşimle doğar, gelişir, çözülür ve yeniden kurulur. Taylor ve Kent'in de (2014) halkla ilişkiler alanında etkileşimi tanımlarken, iki yönlü, ilişkisel, belirli bir amaca yönelik örgüt ve kamular/paydaşlar arasında al-ver ilişkileri kuran, sadece örgütün tek taraflı faydasına değil, tüm tarafların faydasına kararlar yaratan ve tam işleyen bir toplumu teşvik eden bir rolle açıklaması dikkate değerdir. Buradan hareket alarak, etkileşimin iki yönlü doğasını anlamak için ortama bakmak ve ortamı açıklayarak halkla ilişkilerin karar alım süreçlerini değerlendirmek yerinde olur.

\section{Ortam Bileşenleri ve Örgütün Ortamıyla Etkileşimi}

Örgüt teorisyenleri 1960'lı yılların sonlarına kadar örgütün dış ortamı ile ilişkilerinden ziyade örgütün iç ortamı ile ilgilenmişlerdir. Sonrasında popülasyon ekolojisi (Hannan ve Freeman, 1977) ve kaynak bağımlı̆ı̆ı teorileri (Pfeffer and Salancik, 1978) ile örgüt ortam ilişkisi daha da anlaşılmış, örgütün etkinliği ve davranışının açıklanmasında ortam kavramı merkez bir rolle tanımlanmıştır. Ortam, kurumsal teori ile birlikte örgüte meşruiyet kazandırmanın yanında, olumlu algılanmasını sağlayarak varlığını sürdürebilmek için gerekli kaynaklara ulaşmanın da bir ön koşulu olarak ortaya çıkmıştır.

Açık sistem teorisyenlerinin örgütü, varlığını sürdürebilmek için sadece iç sistemleri ile değil dış ortam ile de etkileşim içinde, (Katz ve Kahn, 1966) tıpkı yaşayan bir organizma gibi ortamın etkilerine açık olarak tanımladıklarından beri ortam ve örgüt arasındaki sınırlar da tartışılmaktadır. Biryanda ortamdaki kamuların/ paydaşların tipolojilerindeki belirsizlik ve beklentilerinin tahmin edilemezliği, rekabetin gücü, diğer yanda örgütün kendi politikalarını uygulama ve sürdürme isteği örgütün meşruiyetini, sınırlarını sorgular. Örgütün özerkliği Miller'ın söylediği gibi (1987, s.688) "çevresel zorunluluklar"la zorlanır, sınırlar daha da bulanıklaşır. Burada güç-kontrol perspektifi, örgütlerin ortamdaki çalkantılara ve karmaşalara nasıl adaptasyon sağladıklarıyla ilgili bilgi sunar. Ne var ki, stratejik seçim teorisi çevresel unsurların kolay kontrol edilemeyen zorlamalar olarak görülemeyeceğini, üst yönetimin amaçlarına uygunluk gösterecek şekilde politik müzakereler yoluyla değiştirilip, düzenlenebileceğini ileri sürmektedir. Gulati vd. de (2000) benzer bir çizgide, ortamda örgütün hareketlerini esnetebilecek stratejik ağlardan söz etmiştir. Örgütün etkinliğini sınırlarının ötesindeki kaynakları ne kadar iyi yönetebildiği ile ilişkilendiren Pfeffer ve Salancik de (1978) örgütlerin ortama bağımlılı̆ını azaltacak, nihayetinde örgüte karar alımında da özerklik sağlayabilecek dikey entegrasyon, ortak girişimler, diğer örgütler arası ilişkiler ve politik faaliyetler gibi seçenekler önermektedir. Tam da bu noktada, Center ve Jackson'ın (1995) bahsettiği halkla ilişkiler uygulamalarında istenen sonuçların örgütsel meşruiyet ve özerklik ile ilişkilendirilmesi gerektiğine işaret eden görüşleri dikkate değerdir. Zira örgütün özerkliğini ve yeteneklerini sınırlayan/ geliştiren ortamla ilişkileri inşa etmek halkla ilişkilerin temel meselesidir. O halde halkla ilişkilerin ilişkileri inşa edeceği ortam kavramının ne olduğunu da açıklamak gerekir. 
Ortam kavramsal olarak üç şekilde açıklanmıştır (Jaworski, 1988; Alkhafaji, 2003; Hiriyappa, 2008); macro, görev ve iç ortam. Makro ortam, ulusal ve uluslararası ölçekte sosyal, politik, ekonomik ve teknolojik koşulları açıklarken, görev ortamı örgütle doğrudan bağı olan müşterilerin, çalışanların ve diğer ilgili grupları içine almaktadır. İç ortam ise örgütün işleyişini sürdürdüğü kendi yetki alanına işaret eder. Bu çalışma ortam kavramına yönelik bütüncül bir yaklaşımla, halkla ilişkiler kararlarına etki eden tüm faktörleri değerlendirecektir. Şüphesiz örgütün ortamına uyumu zordur. Zira ortam yapısal olarak hem karmaşık hem de değişkendir ve dahası ortamın koşulları her daim örgütlerin kurumsal yapılarındaki esneklik ile doğru orantılı değişmemektedir. O zaman halkla ilişkiler, ilişkileri başlatacak, geliştirecek, sürdürecek ve hatta koruyacak programların kararlarını nasıl verebilir? Bu soruya yanıt vermek için halkla ilişkilerin karar alımındaki yerini tartışmaya açmak gerekir.

\section{Örgütün Karar Masası ve Halkla İlişkilerin Masadaki Yeri}

Halkla ilişkiler uygulayıcılarının karar alımında ortamdaki hangi bileşenlerden etkilendiğini ortaya dökmek, sadece departman düzeyinde bir açıklamayı olanaksız kılmaktadır. Zira uygulayıcının örgütsel bir sisteme dahil oluşu, karar alımında onu örgütün sınırlarına ve örgüt ile ilgili karar alma-yürütme gücüne sahip gruplara bağlar. Bu grupları Cyert ve March (1963) "baskın koalisyon" adıyla, örgütsel hedefleri etkileyerek örgütsel davranış şekillendiren gruplar olarak tanımlamıştır.

Halkla ilişkiler uygulayıcısının baskın koalisyon masasında yer alması sadece uygulama düzeyinde değil aynı zamanda teorik olarak da karmaşık bir süreçtir. Ancak iletişim boyutlu örgütsel kararlar sözkonusu olduğunda, stratejilerin ve politikaların üretilmesine dahil olması son derece kritiktir. Halkla ilişkiler bu pozisyonla, kendisi dışında bir grubun stratejik seçimleri yapması, kaynaklar ayırması ve halkla ilişkiler programlarını etkilemesi yerine, karar alııılarla ile aynı masada hareket eden bir figür olarak, örgütün işleyişine sağlam bir demir atar. Halkla ilişkiler bu masada artık, hem örgütsel seçimleri, örgütün dünya görüşünü ve uygulamaları yönlendirebilir, hem de mesleki meşruiyetini arttırabilir. Ancak bu iddianın sahada işlerliği tartışmalıdır. Bazı araştırmalarda halkla ilişkilerin karar verme masasında bir yeri bulunmadığı (Tuncer, 2015, Bowen vd. 2006), bulunanların ise kriz zamanlarında (Lee vd., 1999) -kriz öncesinden çok kriz anında- ya da daha spesifik konularda danışman görevi üstlendiği, dahası, kar amacı gütmeyen örgütlerde bazı uygulayıcıların bu masada oturmaya gerek görmediği üzerine saptamalar bulunmaktadır (Fowler, 2015, s.29).

Özetle halkla ilişkiler uygulayıcıları şimdilik iç çemberden dışlanmış görünmektedir. Bu iki nedene bağlanabilir; yönetim halkla ilişkiler rolünü anlamaz ve/veya takdir etmez ya da uygulayıcıların beceri, deneyim ve eğitimi eksiktir. Uygulayıcıların beceri, deneyim ve eğitimi ile ilgili önemli bir araştırma hattı roller üzerinden gitmektedir. Rol araştırmaları halkla ilişkilerin örgütte ne yaptığına odaklandığı kadar uygulayıcıları baskın koalisyon masasına oturtabilecek 
yeterlikleri de açıklamaktadır. Uygulayıcılara biçilmiş en genel roller teknik rol, yönetici rolü (Broom ve Dozier, 1985, 1986) ve stratejist rolüdür (Steyn, 2000) Teknisyen uygulayıcılar metin yazma ve tasarım çalışmaları gibi üretim faaliyetleri yürütürler ancak politikalar ile ilgili kararlarda bulunmazlar. Yöneticiler benzer teknik becerilere sahip olabilirler ancak aynı zamanda problem çözme, stratejik düşünme yeteneklerinin yanında ortamdan bilgi toplama ve analiz etme yetenekleri de vardır. Burada hemen belirtmek gerekir ki uygulayıcılar, uygulayıcıların bazı örgütlerde hem yönetici hem de teknisyen rolünde yer alabilmektedir.

Lauzen ve Dozier (1992) stratejist rolün makro örgütsel düzeyde görevini açıklarken paydaşlar ve makro çevredeki toplumsal konularla ilgili ortam taraması yaparak sınır aşıcı rolünü gerçekleştirdiğinden söz etmektedir. Öte taraftan baskın koalisyonda yer almasa da örgütün politikaları ile ilgili kararlara etki ancak ve sadece masada bir sandalyenin varlığından geçmez. Doğrudan CEO'ya rapor veren uygulayıcıların bu yolla bazı etkiler gerçekleştirebileceğini bu sayede meşru ve hiyerarşik güç sahibi olma olasıııklarının da artabileceği üzerine tartışmalar devam etmektedir (Kanihan vd. 2013; Bowen, 2009). Yine de en yalın haliyle halkla ilişkiler uygulayıcıları ne tatmin edici bir koalisyon erişim seviyesine ulaşabilmiştir, ne de örgütün stratejik planlamasına dahil görünmektedir.

\section{Yöntem}

Araştırma halkla ilişkiler uygulamaları ile ilgili hangi faktörlerin uygulayıcıların karar süreçlerine etki ettiğini ortaya çıkarmayı amaçlamaktadır. Bu amaçla araştırma, üç soruya yanıt aramaktadır; (1) Halkla ilişkiler uygulayıcıları kararlarına etki eden faktörleri nası tanımlıyor? (2) Ortamdaki hangi faktörlerin halkla ilişkiler uygulayıcısının kararlarında merkezi bir önemi var? (3) Bu faktörlerle arasındaki ilişkiler neler? Bu soruların yanıını bulmada bilişsel haritalama yönteminden faydalanılmıştır.

Bilişsel haritalama, fikirlerin, tercihlerin ve söylemlerin aktörlerin konuşma eylemlerinden türetilebileceği ve görsel ve grafik biçiminde temsil edilebileceği, değişkenler arasındaki ilişkilerin bu grafik öğelerle açıklanabileceği fikrine dayanmaktadır (Clarkson ve Hodgkinson 2005). Bu araştırma özelindeki görsel ve grafiksel ifadede, karar ortamı ile en ilgili faktörler ve faktörler arasında farklı bulanık nedensel ilişkileri gösteren oklar yer alır. Nihayetinde haritalar, faktörler arasındaki nedensel ilişkilerin tanımlanmasına ve etkilerinin oluşturulmasına olanak tanıyan bir çıkarım mekanizması olarak öznel dünya ile ilgili algıları ortaya döker. Açık ki, bilişsel haritalar, düşüncelerin temsilinde önemli bir araçtır, sorunu yapılandırmaya yardımcıdır (Ede, 1992; Eden ve Ackermann 1998) ve bu özellikleriyle uygulayıcıları harekete geçiren ve kararlarına yön veren süreçlerin açıklanmasında işlevsel bir yöntem olarak sunulabilir.

Bilişel haritalama yöntemi bu araştırmada üç aşamada gerçekleştirilmiştir. Araştırmanın katılımcıları, uluslararası marka değerlendirme kuruluşu Brand 
Finance'ın hazırladığı Türkiye'nin en değerli 100 markası listesinde yer alan şirketlerin halkla ilişkiler politikalarından sorumlu uygulayıcılarıdır. İlk aşamada uygulayıcılara araştırma konusuyla ilgili bilgilendirici e-postalar gönderilmiş, gönüllü katılımcılar belirlenmiştir.

Araştırmanın ikinci aşaması Aralık 2016 tarihinde başlayan Mart 2017 tarihine kadar süren yüzyüze görüşmelerle devam etmiştir. Yüz yüze görüşmeler bilgilendirici e-postalarar dönüş sağlama sırasına göre düzenlenmiştir. Haritalama öncesi katılımcılardan halkla ilişkiler uygulamaları kararlarına etki eden faktörlerin zihinsel temsiliyle ilgili anahtar kelimeleri ve/veya kısa cümleleri yazmaları istenmiştir. Bunlar araştırmanın uyarıcı metaryallerini oluşturmuştur. Araştırmacılar bu uyarıcılardan toplam 26 değişken elde etmiştir. Bu değişkenler sosyal medya gündemleri, maliyet, itibara katkı, personel yeterliliği, konuyla ilgili bilgi derecesi, çalışmanın süresi, paydaşların psikografik özellikleri, karar alıcılar, yasalar, rakipler, örgütsel politiklara uyum, ülke gündemi, sivil toplum örgütleri, önceki uygulamalara uyum, gelecek uygulamalarar uyum, fırsat yaratıcı potansiyeli, zorunluluk, anlık motivasyonlar, danışman tavsiyeleri, paydaş talepleri, uluslararası yönelimler, etki, medya baskısı, personel motivasyonu, araştırma sonuçları ve pazarlama grafikleridir.

Araştırmanın üçüncü aşamasında katıımcılar 26 değişkeni kullanarak kendilerine sağlanan diyagram sayfasına temel karar problemi için kendi bilişsel haritalarını çizdiler ve değişkenler arasındaki bağlantıları nasıl düşündüklerini gösterdiler. Her bir harita çizimi 38 12 dakika sürmüş, görüşmecinin haritanın yapımını etkilemesi riskini ortadan kaldırmak için katıımcılar araştırma sorusu yöneltildikten hemen sonra yalnız bırakılmıştır. EstimateS 6.0 bl programı ile yapılan doygunluk analizinde 10. görüşmeden sonra çalışmanın doygunluğa ulaştığı görülmüş ve 12. görüşmeden sonra veri toplama çalışması sonlandırılmıştır.

\section{Bulgular}

Araştırmanın ilk aşamasında 12 katılımcı ile gerçekleştirilen yüz yüze görüşmelerde elde edilen katılımcılara ait veriler Tablo 1'de gösterilmektedir. 
Tablo 1. Katılımcılara ait genel bulgular

\begin{tabular}{ccccc}
\hline Katılımclar & Yaş & Cinsiyet & $\begin{array}{c}\text { Mesleki } \\
\text { Deneyim }\end{array}$ & $\begin{array}{c}\text { Departman } \\
\text { Özerkliği }\end{array}$ \\
\hline 1 & 38 & $\mathrm{E}$ & 13 & Var \\
\hline 2 & 44 & $\mathrm{~K}$ & 22 & Var \\
\hline 3 & 41 & $\mathrm{~K}$ & 16 & Var \\
\hline 4 & 37 & $\mathrm{~K}$ & 6 & Var \\
\hline 5 & 53 & $\mathrm{~K}$ & 25 & Var \\
\hline 6 & 51 & $\mathrm{~K}$ & 24 & Var \\
\hline 7 & 29 & $\mathrm{~K}$ & 3 & Yanit yok \\
\hline 8 & 32 & $\mathrm{E}$ & 7 & Var \\
\hline 9 & 48 & $\mathrm{~K}$ & 18 & Var \\
\hline 10 & 42 & $\mathrm{~K}$ & 5 & Yanit yok \\
\hline 11 & 37 & $\mathrm{E}$ & 11 & Var \\
\hline 12 & 25 & $\mathrm{~K}$ & 1 & Yok \\
\hline
\end{tabular}

Tablo 1'de görüldüğü gibi, 12 katılımcının yaş ortalaması 39,75'dir. Katılımcılardan sadece 3'ü erkektir. Mesleki deneyimleri 1 ile 25 yıl arasında değişmektedir. Deneyimlerinin ortalaması 12,5 yıldır. Departman özerkliğine 3 katılımcı yanıt vermemiştir. Bu 3 katılımcının mesleki deneyimleri diğerlerinden azdır.

Araştırma sorusu 1: Halkla ilişkiler uygulayıcıları kararlarına etki eden faktörleri nasıl tanımlıyor?

Uygulayıcıların kararlarını etkileyen değişkenler, EstimateS 6.0 bl doygunluk analizine göre, birinci görüşmeden sonra 12 faktör, dördüncü görüşmeden sonra ise 20 faktör olarak tespit edilmiştir. Dokuzuncu görüşmede ise değişkenler 26 faktöre ulaşmıştır. Tablo 2'de görüşme ve faktör sayıları gösterilmektedir.

Tablo 2. Görüşme ve faktör sayıları eğrisi

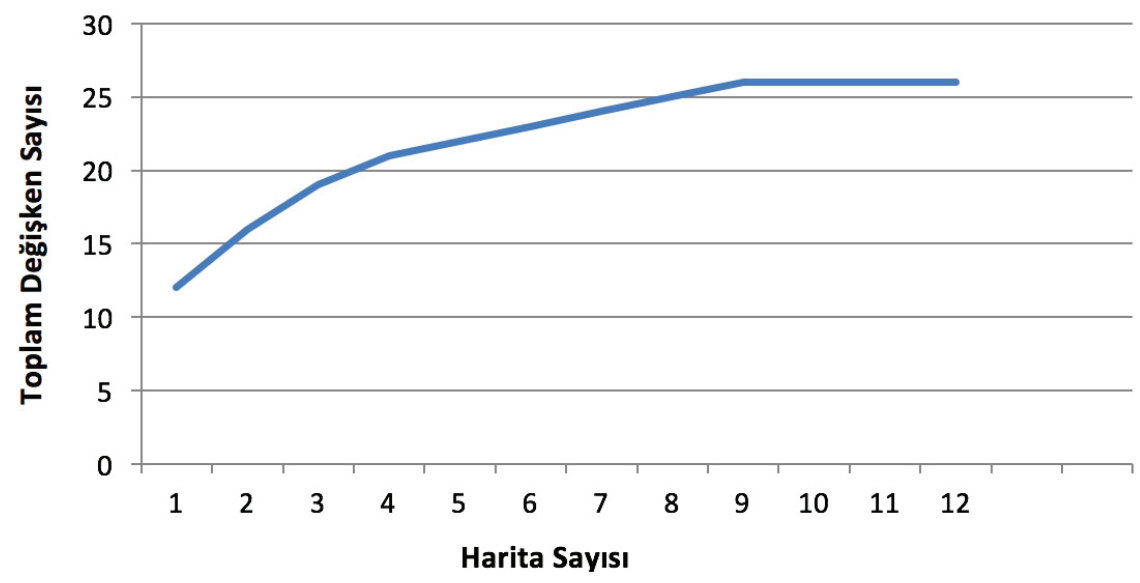


Tablo 2'de görüldüğü gibi dokuzuncu görüşmeden sonra üç görüşme daha gerçekleştirilmiş ancak toplam değişken sayısında ve yeni değişken sayısında herhangi bir artış gözlenmemiş, çalışmanın doygunluğa ulaştığına karar verilmiştir. Tablo 3'te görüşmelerde eklenen yeni değişken sayısı görülmektedir.

Tablo 3. Yeni değişken sayısı

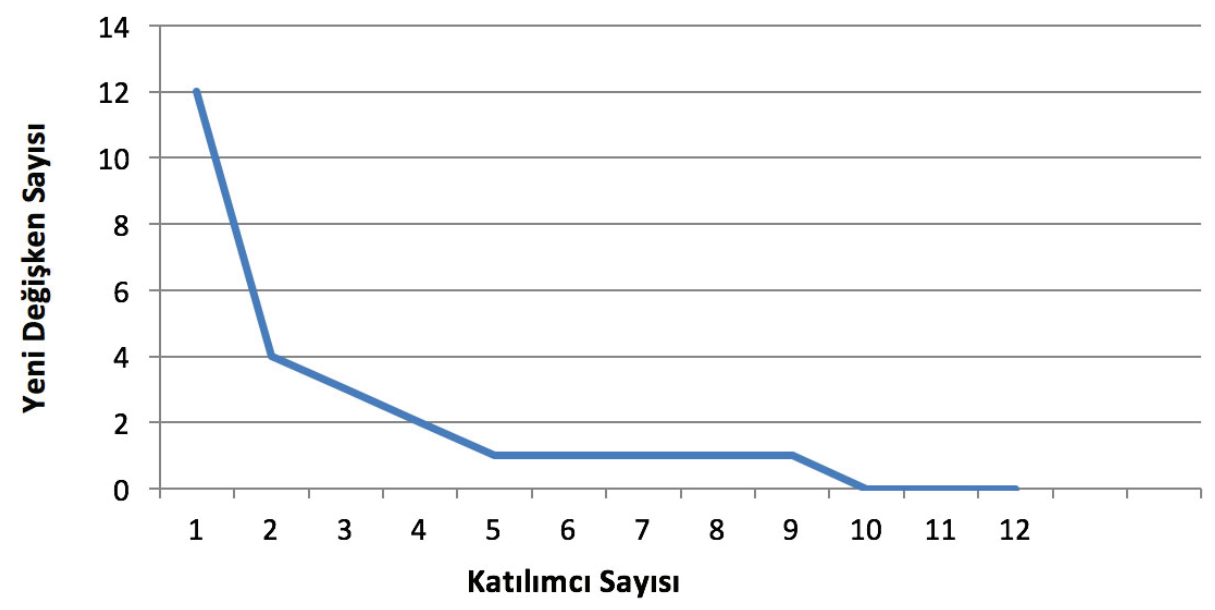

Tablo 3'teki bulgulara dayanılarak 10. görüşmeden sonra halkla ilişkiler kararlarına etki eden yeni bir faktör tanımlaması yapılmamıştır.

Araştırma sorusu 2: Ortamdaki hangifaktörlerin halkla ilişkileruygulayıcısının kararlarında merkezi bir önemi var?

Uygulayıcılarla gerçekleştirilen derinlemesine görüşmeler sonucunda halkla ilişkiler karar alım süreçlerine etki eden 26 faktör belirlenmiştir. Faktörlerin merkeziyet dereceleri Tablo 4'de görünmektedir. Merkeziyet dereceleri bilişsel haritalrda, faktörün önemini işaret etmektedir. 
Tablo 4. Faktörlerin merkeziyet dereceleri

\begin{tabular}{|c|c|c|c|c|c|c|c|}
\hline Sira & Değişken & Merkeziyet & Yoğunluk & Sira & Değişken & Merkeziyet & Yoğunluk \\
\hline 15 & Sosyal medya gündemleri & 80 & 0.012 & 14 & Önceki uygulamalara uyum & 16 & 0.003 \\
\hline & Personel yeterliliği & 33 & 0.004 & 15 & Gelecek uygulamalara uyum & 35 & 0.004 \\
\hline & $\begin{array}{l}\text { Konuyla ilgili bilgi } \\
\text { derecesi }\end{array}$ & 38 & 0.006 & 16 & Fırsat yaratıc1 potansiyeli & 39 & 0.006 \\
\hline & Maliyet & 96 & 0.013 & 17 & Zorunluluk & 43 & 0.007 \\
\hline & İtibara katk1 & 68 & 0.008 & 18 & Anlık motivasyonlar & 74 & 0.010 \\
\hline & Çalışmanın süresi & 18 & 0.003 & 19 & Danışman tavsiyeleri & 39 & 0.006 \\
\hline & $\begin{array}{l}\text { Paydaşların psikografik } \\
\text { özellikleri }\end{array}$ & 44 & 0.007 & 20 & Paydaş talepleri & 53 & 0.007 \\
\hline & Karar alıcilar & 103 & 0.015 & 21 & Uluslararası yönelimler & 29 & 0.004 \\
\hline & Yasalar & 47 & 0.006 & 22 & Etik & 44 & 0.006 \\
\hline & Rakipler & 54 & 0.007 & 23 & Medya bask1s1 & 43 & 0.006 \\
\hline & Örgütsel politikalara uyum & 29 & 0.004 & 24 & Personel motivasyonu & 29 & 0.004 \\
\hline & Ülke gündemi & 66 & 0.008 & 25 & Araştırma sonuçları & 55 & 0.006 \\
\hline & Sivil toplum örgütleri & 41 & 0.006 & 26 & Pazarlama grafikleri & 54 & 0.007 \\
\hline
\end{tabular}

Faktörlerin bilişsel haritalardaki çıkış derecesi ve merkeziyet derecesi gösterge ortalaması $47.15^{\prime}$ dir. Tablo 4'de kuvvetli etkiye sahip faktörler sırasıyla

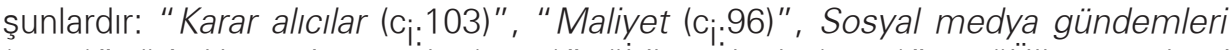

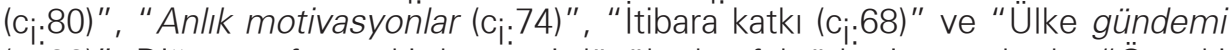
(ci:66)". Diğer taraftan etki derecesi düşük olan faktörler ise şunlardır: "Önceki uygulamaları uyum ( $\mathrm{c}_{\mathrm{i}: 16)}$ ", "Çalışmanın süresi ( $\mathrm{c}_{\mathrm{i}:}$ 18)"; "Uluslararası yönelimler $\left(c_{i}: 29\right)$ ", "Personel motivasyonu ( $\left.c_{i}: 29\right)$ " ve "Örgütsel politikalara uyum ( $\left.c_{i}: 29\right)$ ".

Araştırma sorusu 3: Halkla ilişkiler uygulayıcının kararlarına etki eden faktörler arasındaki ilişkiler neler?

Oluşturulan bilişsel harita, birbirleriyle doğrudan ve dolaylı etkileşime giren faktörlerin ilişki modelini ortaya çıkarmıştır. Faktörlerin merkeziyet dereceleri $\left(c_{i=} o d_{i}+i d_{i} ; i=1,2 \ldots, n\right)$, yoğunluk analizi $(D=c / n)$ ve ulaşılabilirlik şablonu oluşturulmuştur. Bulgular Tablo 5 'te gösterilmiştir. 
Tablo 5. Faktörlerin ilişki modeli, bilişsel haritalama şablonu

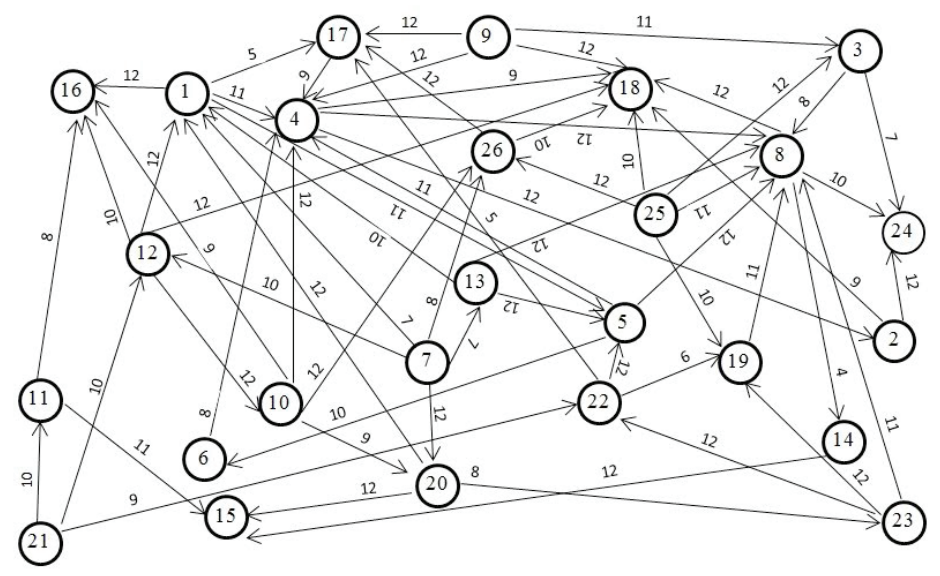

Bu tabloya göre en yüksek bağlantı indeksine sahip faktörlerin yoğunluk dereceleri şu şekildedir: "Karar alıcılar (D:0.015)", "Maliyet (D:0.013)", "Sosyal medya gündemleri (D:0.012)", "Anlık motivasyonlar (D:0.010)", "Ülke gündemi (D:0.008)", “itibara katkı (D:0.008)". En düşük bağlantı indeksine sahip faktörler ve yoğunluk dereceleri şu şekildedir: "Çalışmanın süresi (D:0.003)" ve "Önceki uygulamalara uyum (D:0.003)".

Bilişsel haritalama şablonunun analitik düzleme yerleştirilmesi ile faktörlerin komşuluk analizi oluşturulmuştur (Tablo 6).

Tablo 6. Faktörlerin komşuluk matrisi

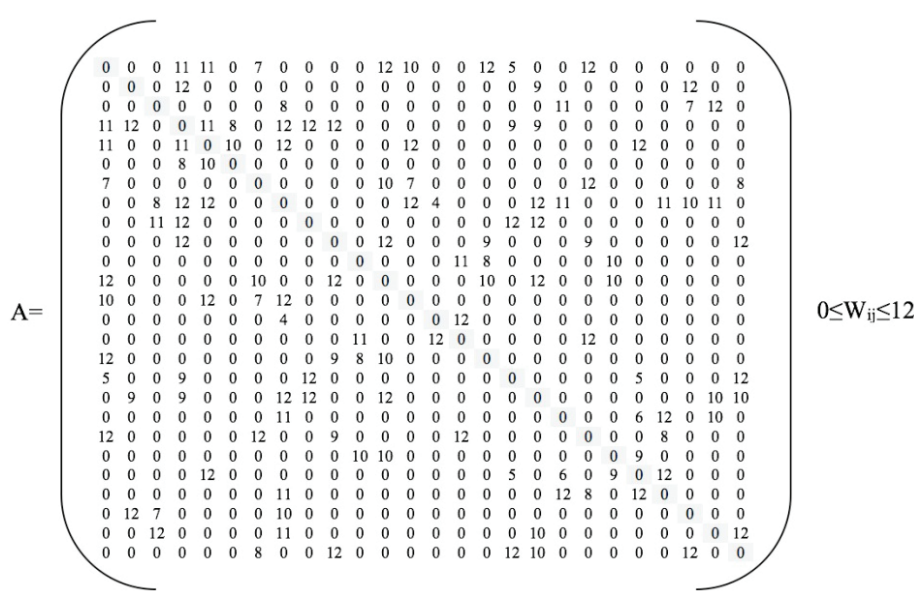


Tablo 6' da faktörlerin diğer faktörler ile ilişki düzeyleri görülmektedir. Ayrıca her bir faktör için satır ya da sütun toplamı o faktörün merkeziyet derecesini ifade etmektedir.

\section{Tartışma}

Halkla ilişkiler uygulayıcılarının karar alımına etki eden çok sayıda faktörün bulgulanması örgütün ortamıyla ilgili bir okumaya olanak tanımıştır. Ortamın karmaşık ve değişken doğası uygulayıcının da farklı faktörlere bağlı kararlar almasına neden olmaktadır. Ancak görünen o ki, kararlarda makro ortamdan daha ziyade iç ortamındaki algılar uygulayıcılar için önceliklidir. Zira haritada görüldüğü gibi en yüksek merkeziyet derecesine sahip değişken "Karar alıcılar" (ci:103) faktörüdür. Karar alıcıların halkla ilişkiler üzerindeki kuvvetli etkisi karar alıcıların yoğunluk derecesinde de görünürdür (D:0.015). Bu sonuç güç kontrol bakış açısıyla örgütsel davranışı belirleyen de örgütün en güçlü kişilerin oluşturduğu baskın koalisyondur. Buna göre halkla ilişkiler uygulayıcısının kararlarının baskın koalisyona yani karar alıcılara dayanması şaşırtıcı ve beklenmedik bir sonuç değildir.

Halkla ilişkiler uygulayıcıları kuvvetli bir biçimde karar alıcılardan etkilenirken uygulayıcılara göre karar alıcılarda, yoğun bir şekilde "Maliyet" faktöründen etkilenmektedir. Örgütün varolma nedeni elbet kar elde etmektir, ancak uygulayıcının kararlarında diğer her şeyden daha çok maliyeti öncelemesi düşündürücüdür. Zira bugünün örgütlerinden toplumsal fayda da üretmeleri beklenmektedir. Ne var ki, araştırma sonuçlarına göre uygulamaların bedeli üreteceği faydadan daha ağır basmış görünmektedir.

"Maliyet" faktörü ile ilgili değinilmesi gereken bir başka sonuç, "Personel yeterliliği" faktörü üzerindeki kuvvetli etkisidir. Uygulayıcıların "personel yeterliliği"ni maliyet ile ilişkilendirerek açıklaması, departmanlaşma bağlamıyla okunabilecek bir sonuçtur. Katılımcılara ait genel bulgularda görüldüğü üzere örgütlerin neredeyse tamamında halkla ilişkiler departmanı bulunduğu tespit edilmiştir. Departmanın maliyeti tek başına istihdam edilen bir uygulayıcıdan şüphesiz fazladır. Ancak "Personel yeterliliği" departmanlaşmayı işaret etmektedir ve halkla ilişkilerin özerkliğini açıklamada değerli bir bulgu olabilir. Zira departmanın varlığı halkla ilişkilerin özerk karar alımına katkı sağlayabilir. Özerklik aynı zamanda etik karar alımı için de elzemdir (Bowen, 2004). Ayrıca bir halkla ilişkiler departmanının varlığı halkla ilişkiler uygulayıcısının kendisini bir karar alııı pozisyonuna getirerek "Karar alıcılar" faktörünün güçlü etkisini kırmaya yarayabilir. Nihayetinde karar alıcıların halkla ilişkiler uygulayıcılarının karar süreçlerinde en merkezi rolü üstlenmesi ve hemen ardından maliyetinin yüksek etki derecesi halkla ilişkiler uygulayıcılarını hala örgütün siperlerinin yüksek sesli savunucuları ya da Grunig'in (1992, s.508) ifadesiyle "başkası tarafından alınmış kararların gerekçelerini açıklayan"lar olduklarını düşündürmektedir. 
Açık ki, maliyet faktörü uygulayıcıların kararlarında önemlidir. Ancak maliyetin uygulamacıdan önce, en azından aynı derecede, baskın koalisyon için de önemli olması beklenir. Aksine, uygulayıcıların algılamalarına göre karar alıcılar, maliyet, araştırma sonuçlarına, sivil toplum örgütlerine, itibara katkıya dayanan kararları diğer faktörlerden daha çok önemsemektedir. Halkla ilişkilerin karar öncelikleri ile ile karar alıcıların öncelikleri farklılık göstermektedir ${ }^{1}$. Karar süreçlerindeki farklı seyreden bu yönün, karar alıcıların uygulayıcılarından farklı kaygılarına bağlı açıklamak mümkündür. Bu kaygıların daha çok örgütün sürdürülebilir karlılık, kar maksimizasyonu, üretim çıktılarındaki dalgalanmalar gibi konularda yoğunlaştığı düşünülmektedir.

"Sosyal medya gündemleri" uygulayıcıların karar alırken önemsediği en yüksek bağlantı ve merkeziyet derecesi indeksine sahip faktörlerden biridir (c;:80). Sosyal medyanın bilişsel haritadaki bağlantı yollarından da kararları güçlü bir şekilde etkilediği anlaşılmaktadır (D:0.012). Bugün sosyal medyanın etki alanı düşünüldügüñde bu sonuç şaşırtıcı değildir. Ancak, sosyal medyada ortaya çıkan yönelimler merkeziyetten uzak, sosyal ağların yapısına uygun olarak dağınık ve yaygındır (Tilly, 2008, s.161). Uygulayıcının ağları takip etmesi, gündemleri analiz etmesi ve değişmeden uygulama kararı vermesi zorlayıcı olabilir. Dahası sosyal medyanın sabun köpüğü gündemleri halkla ilişkilerin makro iletişim stratejilerinde yön kaymasına yol açabilir. Tıpkı sosyal medya gündemleri gibi "Ülke gündemi" faktörü de yüksek indeks değerleri ile (D:0.008; $\left.c_{i}: 66\right)$ dikkat çekmektedir. Her iki faktörün merkeziyet ve yoğunluk dereceleri düşünüldüğünde halkla ilişkilerin bugün, krizleri öngörebilecek veya fırsat yaratabilecek kısa dönemli uygulamalara ne denli önem verdiği açığa çıkmış gibi durmaktadır. Hem sosyal medyanın hem de ülke gündeminin kararlardaki güçlü etkisi "anlık motivasyonlar"ın karar alımlarında neden belirleyici olduğunu açıklamaktadır. Açıkça görülmektedir ki, halkla ilişkiler uygulayıcıları, araştırma sonuçlarından önce gündemlerden hareket almaktadır. Araştırma bulgularındaki "Anlık motivasyonlar" faktörünün yüksek indeks değerleri (D:0.010; $\mathrm{c}_{\mathrm{i}:}$.74) bunu kanıtlamaktadır.

Diğer yandan anlık motivasyonlara dayalı kararlar halkla ilişkilerin sezgisel yönünü karşımıza çıkarmış olabilir. Sosyal medya ve ülke gündeminin her gün ve hatta bazen her saat değişmesi, uygulayıcıların neden anlık motivasyonlara ihtiyaç duyduğunu da açıklayabilir. Uygulayıcıların ne olabileceğini bilme hissi veya güçlü bir sezisi arkasındaki mantığı açıklamaksızın kendi tecrübelerine ya da yargılarına güveni, özellikle hızı karar almasını gerektiren durumlarda uygulayıcının kararlarına yön vermektedir. Öyle ki, bilginin yetersiz olduğu ve çözüme ulaşılamadığı o an, sezgiler karar almanın merkezinde yer bulur. Aslında Miller ve Ireland (2005) birçok yöneticinin sezgiyi stratejik karar alma sürecinde etkili bir yaklaşım olarak kabul ettiğini iddia etmektedir. Agor (1989) ve Seebo (1993) ise sezgisel karar alma ile deneyim süresi arasında pozitif bir ilişki keşfetmiştir. Nihayetinde katıımcıların deneyim süresi göz önüne alındığında ortalamanın 12,5

1 Yazarlar bu sonucu, halkla ilişkiler uygulayıcılarının algılarına dayalı değerlendirmiştir. 
yıl olduğu tespit edilmiştir. Bu bulgu ile anlık motivasyonların kararlara etkisinin bu derece merkezde yer alması daha da anlaşılır olmaktadır.

Sosyal medya gündemleri ve ülke gündeminin halkla ilişkilere yön vermesi elbette beklenen bir sonuçtur. Ancak bu faktörlerin merkeziyet derecesi bu denli yüksekiken, "Paydaş talepleri" ve "Paydaşların psikografik özellikleri" faktörlerinin merkezden uzak olması tartışmaya değer bir bulgudur. Bu bulgu, haber değeri yüksek uygulama arayışlarının yoğunluğu hakkında bir fikir vermektedir. Görünen o ki, uygulayıcılar anlık motivasyonlardan yola çıkan popüler ve daha az maliyetli uygulamalar üretmenin peşindedir. Yukarıdaki tartışmalarda da değinildiği gibi maliyet faktörü uygulayıcılar için ilk sıradan hemen sonra gelmektedir. Halkla ilişkilerin gündemde olanın peşine düşmesi, maddi kaynakların daha rafine kullanımını mümkün kılabilir. Ancak bu sonuç maksimize edilmiş faydanın ağırlıklı olarak örgüt yanlı olduğunu düşündürmektedir.

Gündemlerin önemi, anlık motivasyonların kararlardaki güçlü etkisi uygulayıcının, sınır aşıcı rolünün gereğini bir ölçüde yerine getirdiğine işaret etmektedir ancak, örgütün ortamdaki beklentilerden etkilenerek ortama uyum sağlaması söz konusu olduğunda uygulayıcı ile ortamı arasında karar alıcılar ve maliyet bir duvar gibi durmaktadır. Aksi bir resimde, halkla ilişkiler örgütte güçkırıcı bir pozisyonla işlev görse, örgüt içinde farklı sesler için alan yaratabilir ve bu alanlar ortamın aktörlerinin isteklerini resmileştirmekle kalmaz halkla ilişkiler uygulayıcısını da bir çeşit sosyal eylemciye dönüştürebilir. Lakin, halkla ilişkilere biçilen örgüt içindeki bu aktivist rol, araştırmanın sonuçlarına bağlı olarak şimdilik oldukça uzak görünmektedir.

Araştırma sonuçlarında "Sivil toplum örgütleri" faktörünün merkeziyet derecesi gösterge ortalamasının altında kaldığı görülmektedir (c;:38). Sivil toplum, hegemonik yapıdan farklı olarak normatif bir sosyal alan modeline dayanır. Bu modelin temel özellikleri farklılığı merkeze alan, çoğulculuk, kültür ve iletişim kurumlarını yükselten, kamusallık ve kişisel tercihlere özerklik tanıyan mahremiyettir (Cohen ve Arato, 2013, s.312). Öz yönetim mekanizmaları ile programlanmış sivil toplum örgütleri, karar alım süreçlerinde konumlanan birer faktör olarak toplam sonuçların demokratikleşmesi ve toplumsal faydanın öne çıkması açısından kilit bir görev üstlenir. Halkla ilişkiler kararlarında "Sivil toplum örgütleri" faktörünün etkin bir değişken olmaması, ortam baskının temel unsurlarından biri olması beklenen gelişmiş bir sivil toplum anlayışının genel bir eksikliği ve toplum kültüründe sivil toplum kuruluşlarının nüfuz alanı bulamaması ile ilgili olabilir2.

Diğer taraftan bilişsel haritada sivil toplum örgütlerinin "karar alıcılar" ve "itibara katkı" faktörleri üzerinde kuvvetli bir etkisinin olduğu görülmektedir. Karar

2 Türkiye Cumhuriyeti İçişleri Bakanlığı'ının 2013 yılında yayımladığı "çeşitli ülkelerin sivil toplum kuruluşları sayısının karşılaştıııması" çalışması Türkiye'de STK başına düşen kişi sayısının G20 ülkeleri ortalamasının oldukça altında olduğunu göstermiştir. 
alıcıların sivil toplum örgütlerinden kuvvetli bir şekilde etkilenmesi, örgütlerin baskın güçlerinin dengelenmesinde gelecek için umut verici bir bulgudur. Sivil toplum örgütlerinin bir diğer bağlantı yolu "sosyal medya gündemleri" faktörüyledir. Sivil toplum örgütlerinin yüksek ağ potansiyeli düşünüldügünde, sosyal medyada popüler gündemler oluşturma ve buna bağlı gündemleri belirlemedeki yetkinliği anlaşılır olmaktadır. Bu nedenle uygulayıcılar sivil toplum örgütlerini duymadaki eksikliğini gündemleri takip ederek kapatmaya çalışıyor olabilir.

Uygulama kararlarına etki eden "Çalışmanın süresi" faktörü katılımcılar tarafından "Itibara katkı" ve "Maliyet" ile ilişkilendirilmiştir. Bulgular uzun süreli çalışmaların yüksek maliyet getirdiğini ortaya çıkarmıştır. Buna rağmen, "Çalışmanın süresi" faktörünün oldukça düşük merkeziyet derecesi ( $c_{i}$ 18) halkla ilişkiler programlarının genellikle kısa süreli çalışmalarla oluşturulduğunu göstermektedir. Bir halkla ilişkiler programının uzun süreye yayılması aynı zamanda önceki ve sonraki çalışmalara uyumuna ilişkin bir zorunluluğu da beraberinde getirir. Ne var ki, araştırma sonuçları "Önceki uygulamalara uyum" ( $\left.c_{i}: 16\right)$ ve "Gelecek uygulamalara uyum" ( $\left.c_{j}: 33\right)$ faktörlerinin de ortalamanın altında merkeziyet derecesine sahip olduğunu göstermektedir. Dolayısıyla "Çalışmanın süresi" faktörünün düşük indeks değerleri "Önceki uygulamalara uyum" ve "Gelecek uygulamalara uyum" faktörlerinin düşük indeks değerleriyle uyumludur.

Önceki tartışmalardan hatırlanacağı gibi, "Anlık motivasyonlar" faktörünün hem merkeziyet derecesi ( $\left.c_{i}: 64\right)$ hem de yoğunluk indeksi (D:0.010) yüksektir. Bu faktörün bilişsel haritadaki etkileşimleri ile "Çalışmanın süresi", "Önceki uygulamalara uyum" ve "Gelecek uygulamalara uyum" faktörlerinin düşük indeksleri bir arada değerlendirildiğinde halkla ilişkiler uygulamalarının hazlihazırda uzun vadeli planlardan uzaklaştığı, daha çok anlık kararlarla örüntülendiği açıkça görülmektedir.

Ne var ki, anlık motivasyonlarla alınan kararların stratejik programlar oluşturmaya yetmeyeceği bir gerçektir; zira bu kararlar uygulayıcının öngörülerine bağlıdır, araştırmaya dayalı analizlerden elde edilmiş verilerle kurgulanamazlar. Oysa stratejik bir iletişim örgütün misyonunu ve konu ile ilgili ortam koşullarını analiz etmeyi ve çözümlemeyi, sonra da ilerideki karar ve sonuçlar için bir kılavuz oluşturacak şekilde bu unsurları birleştirmeyi gerektiren bir süreçtir. Bu tanım konuya dair araştırmaların yapılmasını elzem kılar ve "Araştırma sonuçları" (c;:55; D:0.007) faktörünün ortalamaya yakın indeks değerleri dikkate alındığında, halkla ilişkiler programlarının sınırlı bir alan dışında stratejik bir programla yönetilmediği varsayımını güçlendiren sonuçlar ortaya çıkarmaktadır. Çünkü stratejik bir programın başlangıç noktası kantitatif ve kalitatif verilerin toplanması ve analizidir. Böylece örgüt beklentileri tespit edilen ortamıyla işbirliği geliştirir ve aynı zamanda kendisini şeffaflaştırır ve anlaşılabilir kılar. Aksine, uygulayıcıların uygulamalara karar verirken araştırma sonuçlarına yeterli önemi vermemesi "Paydaş 
talepleri" faktörünün neden bu denli düşük indeks değerleri ile bulgulandığını da anlatmaktadır.

Bilişsel harita şablonunda "Araştırma sonuçları" faktörünün güçlü bir şekilde "Konuyla ilgili bilgi derecesi" faktörünü etkilediği görülmektedir. "Konuyla ilgili bilgi derecesi" faktörü de "Personel motivasyonu" faktörü üzerindeki olumlu bir etki yapmış görünmektedir. Bu bulguya göre uygulayıcılar konuyla ilgili araştırmalar yaparak bilgi derecelerini arttırırlar ve böylece progrmlarını motive olmuş bir şekilde hazırlarlar ve uygularlar. Diğer yandan elinde veri olan uygulayıcının kendisini daha yetkin hissettiğini gösteren sonuç, uygulayıcıların araştırma sonuçlarındaki hangi verileri hangi yetkinliklerine göre nasıl kullandığına ilişkin de bir merak doğurmuştur. Demek ki, araştırma sonuçları faktörü olmadan anlık motivasyonlarla hareket eden uygulayıcılar, araştırma verilerine dayanan kararlar aldıklarında aslında daha motive olmaktadır.

Özetle karar alıcıların, maliyetin, sosyal medya gündemlerinin ve anlık motivasyonların karar alımına etkisi anlaşıldığı gibi merkezdedir. Bu merkezden biraz ötede uygulamaların itibara yapacağı katkı karar almada uygulayıcıların dikkate aldığı başka bir faktör olarak yer almaktadır. İtibarın örgüt performansına etkisi halkla ilişkiler yazınında tartışılmaya devam etmektedir (Shirin ve Kleyn, 2017; Chen vd., 2017; Chao, 2017) Uygulayıcıların itibara katkıyı, kararlarını etkileyen yirmi altı faktörden beşinci sıraya koymaları da yazınla paralleliği göstermektedir. İtibara katkı sağlayacak kararlar değerini ilk sıralarda bulmuştur, fakat itibara katkı faktörünün en çok karar alıcılar ve çalışmanın süresi faktörleri ile ilişkilendirilmiş olması daha dikkat çekicidir. Karar alıcılar itibara katkı sağlayacak kararları desteklemektedir. Örgütün itibarının en az maliyet kadar önemli olduğu nihayetinde örgütün varolma sebebi ile eşdeğer algılandığı bugünün örgütleri için itibar sağlayacak kararların ne denli değerli olduğu anlaşılmaktadır. Yine de halkla ilişkiler uygulayıcısının kararlarında gündemlerden sonra gelen itibara katkı, baskın koalisyon masasında daha önemli bir yer teşkil etmektedir. Şu ana kadarki tartışmalarda halkla ilişkilerin kısa süreli programlara verdiği değer, gündemlerin ve anlık motivasyonlar faktörlerinin merkeziyet derecesi göz önüne alınarak açıklanmıştır. Ancak itibar uzun süreli programlarla oluşturulan paydaşların örgüt ile ilgili değerlendirmelerinin sonucu olarak tanımlanmaktadır (Dowling, 2001, s.19). Demek ki, halkla ilişkiler uygulayıcıları kısa süreli programlardan da itibara katkı sağlamasını beklemektedir.

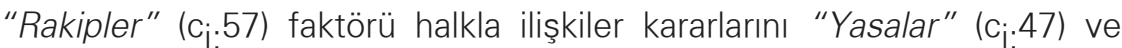
"Etik" (ci:44) faktörlerinden daha merkezi bir derece ile etkilemektedir. DiMaggio ve Powell'ın (1983) yeni kuramsal kuram teorisi ekseninde açıkladığı "taklit eşbiçimsellik" ile örgütler meşruiyetine inandıkları başka örgütlerin uygulamaları ile eşbiçimlenir. Bazen örgütler daha güçlü başka örgütlerin -meslek örgütleri ya da profesyonel örgütler de dahil olmak üzere- baskılarıyla karar almak zorunda kalır. Bu kurumsal çevrenin getirdiği bir zorunluluktur. Halkla ilişkiler 
uygulamacılarının kararlarına etki eden "zorunluluklar" ( $c_{i:}$ 43; D:0.007) faktörü de bu sebeple açıklanabilir. Bu zorunluluklar rutin uygulamaları da (özel gün ve haftalardaki kutlamaları gibi) içine almış olabilir. Normatif unsurlara göre, sosyal düzen, sadece yasalarla değil, daha geniş sosyal değerlere uyumlu olma yoluyla sağlanabilir (Ruef ve Scott, 1998, s.877).

Buna ek olarak, "aşk ve nefret" (Larsson 2009, s.136) ilişkisinin bir tarafındaki gazeteciler yani "medya baskısı" faktörü, halkla ilişkiler uygulayıcılarının kararlarında etki etmiş görünmektedir. Burada katılımcıların baskı kavramını kullanması, araştırmacılara baskının kararlara etkisinin rutin zamanlardan daha çok örgütün etik ihlallerinde var olduğunu düşündürmüştür.

"Etik" faktörünün karar alımındaki yeri, araştırmacıların umduğu merkezden oldukça uzaktadır. Bu durum Parsons'ın (2016, s.4) sorusunu akla getirir; halkla ilişkiler ve etik birbirine tezat mıdır? Bulgular, Pratt'ın (1994) halkla ilişkilerin doğasının uygulayıcıların etik kaygılar yerine örgüt yönlü karar vermenin girdabına ittiğine ilişkin fikrinin hala geçerli olduğuna ilişkin bir görünümdedir. "Yasalar" ve "etik" faktörünün merkeziyet dereceleri birbirine çok yakındır. Yasaların az da olsa etikten karar merkezine daha yakın olması, Bowen'ın (2008, s.218) neyin yasal olduğunu bilmenin neyin etik olduğunu bilmekten genellikle daha kolay olduğuna ilişkin bulgularını destekler gibidir. Halkla ilişkiler uygulayıııları da her etik sorunun yasal bir çerçevesi olduğuna inanmış olabilirler.

\section{Sonuç ve Öneriler}

Araştırma sonuçları halkla ilişkilerin özündeki "etkileşimi" işletmekte olduğunu açıkça göstermektedir. Ne var ki, etkileşimdeki karşılıklı etki tek yönlüdür, daha çok örgütün ortamından etkilenmesi biçiminde görünmektedir. Yani örgütün ortamına uyumundan çok, ortamından etkilenmesi biçimiyle asimetrik bir ilişki daha geçerli durmaktadır. Uygulayıcıların paydaş beklentilerini analiz etmekten uzak tutumu, araştırmalar yerine sezgilerine güvenen uygulayıcıların varlığını göstermektedir. Diğer taraftan uygulayıcıların beklentilerden etkilenmesi söz konusu olduğunda, uygulayıcı ile ortamı arasında karar alıcılar ve maliyet durmaktadır.

Halkla ilişkiler uygulayıcıları, sosyal medya ve ülke gündemlerini yakından takip ederek, ortamda nelerin olup bittiğini görmektedir. Öyle ki, kararlarda önemli bir etkiye sahip sosyal medya, cazibesiyle, halkla ilişkiler uygulayıcılarını itibara katkı, paydaşların beklentileri, yasalar ve diğer pek çok faktörden çok daha fazla etkilemiştir. Etik faktörü de uygulayıcıların karar alımını etkileyen bir faktör olmasına karşın hakettiği değerden oldukça uzaktadır. Etik değerlerin uygulamalara karar verirken alt sıralarda yer alması şu soruları yeniden akla getirmiştir; geçilmemesi gereken etik çizgisi nedir? Bir halkla ilişkiler uzmanı 
için kendisini ve çalıştığı kurumu bile feda etmesi gereken "toplumsal iyi" hangi noktada başıyor? Bu çizgi nasıl belirlenecek? Böyle bir çizgi varsa onu geçtiğimizi nasıl anlayacağız? (Miyamoto, 1996'dan aktaran, Gökmen, 2012). Miyamoto'nun sorularına Wright'ın (1993) "halkla ilişkilerin etiğe rehberlik etmesi için hazırlanmış mesleki kodların fazla genel ve mantıksal çelişkilerle dolu" tespiti eklendiğinde etik kararlarla uygulamaların nasıl yönetileceği sorusuna verilecek yanıtlar daha da belirsiz bir hal almaktadır.

Nihayetinde sosyal medyanın ve ülke gündeminin hızla değişen doğası uygulayıcıların anlık motivasyonlarla karar vermesine neden olmaktadır. Türkiye özelindeki bu bulgular Lee ve diğerlerinin (2015) özellikle genç uygulayıcıların sosyal medya uzmanı olarak da bir işlev gördüklerini açıklayan araştırma ile örtüşmektedir.

Uygulamaların araştırma sonuçlarına değil popüler gündemlere bağlı kararları halkla ilişkilerin sınır aşıcı bir rol üstlenmesini sağlamış görünmektedir. Ancak belirtmek gerekir ki, Tushman'ın (1977) tanımladığı sınır aşıcı (boundary spanning) rolü bundan daha fazlasını ifade etmektedir. Fakat bu rolde halkla ilişkiler uygulacısının örgütü savunma ve ortamdaki diğer aktörlerle uzlaşma arasındaki etik ikilemleri derindir. Karar alıcıların ve maliyetin en merkezde halkla ilişkiler uygulamalarına yön veriyor oluşu bunun açık bir kanıtı olarak okunmalıdır. Uygulayıcıların algılamalarına göre, karar alıcıların kararlarına etki eden faktörlerin uygulayıcılardan farklı bir yönde olması, örgütün sınırları dışındaki bilgileri toplayabilse dahi, halkla ilişkilerin örgütte bir sözcüden öteye gitmediğini göstermektedir. Belki de gündeme dair anlık popüler üretimler, maliyet hassasiyeti ve karar alıc taleplerinin merkezilenmesi, Grunig ve Hunt'ın (1984) açıkladığı basın ajansı modelinin günümüzdeki bir görünüşü olabilir. Bu dikkat çekici bir şüphedir ve halkla ilişkilerin karar alım süreçleri ve kararların sonuçlarına yönelik başka araştırmalar yanıtları bulmada fayda sağlayabilir. Diğer yandan sezgisel halkla ilişkilerin stratejik halkla ilişkilerdeki -varsa- değerini anlamaya yönelik çalışmalarda dikkat çekici sonuçlar elde edilebilir. Uygulayıcıların uluslararası yönelimlere karar alımında son sıralarda yer vermesinin nedenleri ile ilgili bir araştırma ilgi çekici sonuçlara ulaşabilir. Sivil toplum örgütlerinin ortam baskısı olarak clız bir aktör olması, toplumsal faydanın üretilmesinde nasıl bir etki yapmaktadır sorusuna yanıt verecek sivil toplum örgütlerine odaklanan bir çalışma yapmak alana önemli katkılar sağlayacaktır. Son olarak bu araştırmanın bir kısıtı başka araştırmalar için yeni bir başlangıç noktası olabilir. Bu araştırmada karar alıııların algıları halkla ilişkiler uygulayıcılarının değerlendirmelerine bağı kalınarak açıklanmışır. Dolayısıyla uygulayııının ve karar alıcıların kararlara nasıl etki ettiğini her iki grup için hazırlanacak ayrı haritalar ortaya daha açık dökebilir. 


\section{Kaynakça}

Agor, W.H. (1989). Intuition and Strategic Planning: How Organisation Can Make Productive Decisions. The Futurist, 23, 20-23.

Alkhafaji, A.F. (2003). Strategic Management: Formulation, Implementation, and Control in a Dynamic Environment. New York: Haworth.

Botan, C. H., Taylor, M. (2004). Public Relations: State of The Field. Journal of Communication, 54, 645-661.

Bowen, S.A, (2004). Organizational Factors Encouranging Ethical Decision Making: an Exploration into The Case of An Exemplar. Journal of Business Ethics, 52, 311-324.

Bowen A.S. (2008). A State of Neglect: Public Relations as 'Corporate Conscience' or Ethics Counsel, Journal of Public Relations Research, 20(3), 271-296.

Bowen Shannon A. (2006). Autonomy in Communication: Inclusion in Strategic Management and Ethical Decision-Making. A Comparative Case Analysis. Journal of Communication Management, 10(4), 330-352.

Broom, G.M., Dozier, D.M. (1985). Determinants and Consequences of Public Relations Roles. Paper presented at the meeting of the Association for Education in Journalism and Mass Communication, Memphis, TN.

Broom, G. M., Dozier, D. M. (1986). Advancement for Public Relations Role Models, Public Relations Review, 12, 37-56.

Byrd, S. (2012). Hi Fans! Tell Us Your Story!: Incorporating A Stewardship Based Social Media Strategy To Maintain Brand Reputation During A Crisis, Corporate Communications: An International Journal, 17(3), 241-254.

Center, A.H., Jackson, P. (1995). Public Relation Practices: Management Case Studies and Problems (5.Baskı). Englewood Cliffs, NJ: Prentice Hall.

Chao, E.J. (2017). Core Corporate Strategic Capabilities: Role of Corporate Capabilities, Integrity, Institutions, and Implications Toward Sustainable Corporate Reputation and Performance. In: Campbell C.L. (Ed.), The Customer is NOT Always Right? Marketing Orientationsin a Dynamic Business World içinde (759-859). New York: Springer.

Chen, M.C., Nguyen, B., Melewar, T.C., Dennis C. (2017). Investigating the Uses of Corporate Reputation and Its Effects on Brand Segmentation, Brand Differentiation, and Brand Positioning: Evidence from the Taiwanese Pharmaceutical Industry, International Studies of Management \& Organization, 47(3), 240-257.

Clarkson, G.P., Hodgkinson G.P. (2005). Introducing CognizerTM: A Comprehensive Computer Package for The Elicitation and Analysis of Cause Maps. Organizational Research Methods, 8(3), 317-341. 
Cohen, L.C., Arato, A. (2013). Sivil Toplum ve Siyasal Teori. Ankara: Efil Yayınevi Yayınları.

Cyert, R. March, J. (1963). A Behavioral Theory of The Firm. Englewood Cliffs, $\mathrm{NJ}$ : Prentice Hall.

DiMaggio, J.P., Powell, W.W. (1983). The Iron Cage Revisited: Institutional Isomorphism and Collective Rationality in Organizational Fields, American Sociological Review. 48(2), 147-160.

Dowling, R.G., (2001). Creating Corporate Reputation. Oxford: Oxford University Press.

Dhanesh, S.G. (2017). Putting Engagement in Its Proper Place: State of The Field, Definition And Model of Engagement in Public Relations. Public Relations Review, 43.

Edelman, R. (30 Ocak 2008). Public Engagement: The Evolution of Public Relations . Erişim: 08 Ocak 2017, http://www.instituteforpr.org/wp-content/ uploads/Edelman_2008_Lecture.pdf

Eden, C., Ackermann, F. (1998). Making Strategy: The Journey of Strategic Management. London: Sage Publication.

Eden, C. (1992). On The Nature of Cognitive Maps, Journal of Management Studies, 29(3), 261-265.

Fowler, T. (2015). Dominant Coalition Perceptions in Health-Oriented, Nonprofit Public Relations. Yayınlanmamış Yüksek Lisans Tezi, Ball State Üniversitesi.

Grunig, J.E., Hunt, T. (1984). Managing Public Relations. ABD: ThomsonWadsworth Learning Inc.

Grunig, J.E., (Ed.) (1992). Excellence in Public Relations and Communication Management. Hillsdale, NJ: Lawrence Erlbaum Associates.

Gökmen M., (2012). Halkla İlişkiler ve Medya İlişkisi: Özerklik mi Bağımlıık mı?. Erişim: 02 Şubat 2017. http://bianet.org/biamag/medya/140114-ozerklik-mibagimlilik-mi

Gulati, R., Nohria, N., Zaheer, A. (2000). Strategic Networks. Strategic Management Journal, 21 (3), 203-215.

Hannan, M.T., Freeman, J.H. (1977). The Population Ecology of Organizations, American Journal of Sociology. 82 (5), 929-964.

Harun, C., (2010). Kaynak Bağımlılığı, İşlem Maliyetleri, Örgütsel Ağ ve YeniKurumsal Kuram ile Örgütlerin İttifak Oluşturma Sebepleri Üzerine Bir İnceleme. Meydan Savunma Bilimleri Dergisi, 9(2), 17-40.

Hiriyappa, B. (2008). Strategic Management. New Delhi: New Age International. 
Holtzhausen, R.D. (2000). Postmodern Values in Public Relations. Journal of Public Relations Research, 12 (1), 93-114.

Huo, Y.J., Binning, K.R., Molina L.E. (2010). Testing an Integrative Model of Respect: Implications for Social Engagement and Well-Being. Personality and Social Psychology Bulletin, 36(2), 200-212.

Jaworski, B.J. (1988). Toward a Theory of Marketing Control: Environmental Context, Control Types, and Consequences. Journal of Marketing, 52, 23-39.

Johansen, T.S., Nielsen, A.E. (2011). Strategic Stakeholder Dialogues: A Discursive Perspective On Relationship Building. Corporate Communications: An International Journal, 16(3), 204-217.

Kanihan, S.F., Hansen, A.K., Blair, S., Shore, M., Myers, J. (2013). Communication Managers In The Dominant Coalition: Power Attributes and Communication Practices. Journal of Communication Management, 17(2), 140156.

Kast F.E., Rosenzweig, J.E. (1972). General Systems Theory: Applications for Organization and Management. Acad Manage J, December, 1.

Katz, D., Kahn, R.L. (1966). The Social Psychology of Organizations. New York: Wiley.

Kim, S., Lee, Y.J. (2012). The Complex Attribution Process of CSR Motives, Public Relations Review, 38(1), 168-170.

Larsson, L. (2009). PR and The Media: A Collaborative Relationship?, Nordicom Review, 30(1), 131-147.

Lauzen, M. M., Dozier, D.M. (1992). The Missing Link: The Public Relations Manager Role as Mediator of Organizational Environments and Power Consequences for the Function. Journal of Public Relations Research, 4(4), 20520.

Lee, J., Stella M.J., Robert L.H. (1999). Decision-Making Encroachment and Cooperative Relationships Between Public Relations and Legal Counselors in the Management of Organizational Crisis. Journal of Public Relations Research, 11(3), 243-270.

Lee, S., Kim, B. (2015). A Time-Series Analysis of International Public Relations Expenditure and Economic Outcome. Communication Research, April, 1-9.

Macnamara, J. (2016). Organizational Listening: Addressing A Major Gap in Public Relations Theory and Practice. Journal of Public Relations Research, 28(34), 146-169.

Men, L.R., Tsai, W.H.S. (2014). Perceptual, Attitudinal, and Behavioral Outcomes of Organization - Public Engagement on Corporate Social Networking Sites. Journal of Public Relations Research, 26(5), 417-435. 
Mersey, R.D., Malthouse, E.C., Calder, B.J. (2012). Focusing on The Reader: Engagement Trumps Satisfaction. Journalism \& Mass Communication Quarterly, 89(4), 695-709.

Miller, C.C., Ireland, R.D. (2005). Intuition in Strategic Decision Making: Friend or Foe in The Fast-Paced 21st Century. Academy of Management Executive, 19, 19-30.

Miyamoto, C. (1996). Public Relation Ethics 201: Challenges We Just Can't Ignore. Presented at Mega Comm'96, Hawaii.

Parsons, J.P. (2016). Ethics in Public Relations: A Guide to Best Practice (Third Edition). Kogan Page Limited.

Palmer, D.A., Biggart, N. W., (2002). Organizational Institutions. Baum J. A. C. (Ed), The Blackwell Companion to Organizations içinde (259-328). Oxford: Blackwell.

Pfeffer, J., Salancik, G. (1978). The External Control of Organizations: A Resource Dependence Perspective. New York: Harper and Row.

Ruef, M., Scott, W.R., (1998). A Multidimensional Model of Organizational Legitimacy: Hospital Survival in Changing Institutional Environments. Administrative Science Quarterly, 43(4), 877-904.

Seebo, T.C. (1993). The Value of Experience and Intuition. Financial Management, 22(1), 27.

Shirin, A., Kleyn, N. (2017). An Evaluation of the Effects of Corporate Reputation on Employee Engagement: The Case of a Major Bank in South Africa. International Studies of Management \& Organization, 47(3), 276-292.

Sriramesh, K., Vercic, D. (2003). A Theoretical Framework for Global Public Relations Research and Practice. Sriramesh, K. ve Vercic, D. (Ed.), The global public relations handbook; theory, research, and practice içinde (1-19). New Jersey: Lawrence Erlbaum Associates.

Steyn B., Niemann, L. (2010). Enterprise strategy: A Concept That Explicates Corporate Communication's Strategic Contribution at The Macro-Organisational Level. Journal of Communication Management, 14(2), 106-126.

Steyn, B., (2000). Strategic Management Roles of The Corporate Communication Function. Yayınlanmamış Yüksek Lisans Tezi, Pretoria Üniversitesi.

Taylor, M., Kent, M.L. (2014). Dialogic Engagement: Clarifying Foundational Concepts. Journal of Public Relations Research, 26(5), 384-398.

Tilly, C. (2008). Contentious Performances. Cambridge: Cambridge University Press.

Tushman, L.M. (1977). Special Boundary Roles in the Innovation Process. Administrative Science Quarterly, 22(4), 587-605. 
Tuncer, A. (2015). Kurumsal Yönetim Ilkeleri ile Mükemmel Halkla Ilişkiler Bağı Üzerine Bir Analiz. Iletişim Kuram ve Araştırma Dergisi, Bahar, 40, 2-15.

Vivek, S.D., Beatty, S.E., Morgan, R.M. (2012). Customer Engagement: Exploring Customer Relationships Beyond Purchase. Journal of Marketing Theory and Practice, 20 (2), 122-146.

Wright, D. K. (1993). Enforcement Dilemma: Voluntary Nature of Public Relations Codes. Public Relations Review, 19, 13-20. 